\title{
Problems and Countermeasures of Aviation Industry Development in Henan Province
}

\author{
Shaoxia Zhao * \\ Administrative Engineering College, Zhengzhou University, Zhengzhou, China \\ Corresponding Email: 1358804759@qq.com
}

\begin{abstract}
With the rapid development of China's aviation industry, the province is also accelerating the pace of development of the aviation industry, but in the high-speed development also encountered some problems. This paper starts from the current situation of the aviation industry in Xinzheng airport pilot area of Henan Province, and then briefly introduces the development of aviation industry in Henan Province. On this basis, it points out that the high - end talent shortage in the development of Henan's aviation industry and the effect of enterprises' agglomeration have not been formed. The countermeasures are put forward to perfect the traffic system, build the green aviation city, strengthen the government guidance, esteem the innovation, improve the technical content of the products and enhance the industrial competitiveness. Finally, based on the current development of the aviation industry, the future development prospects of aviation industry in our province are forecasted.
\end{abstract}

\section{The development status of aviation industry in Henan province}

In Henan, there are 13 aerospace and spacecraft manufacturing enterprises. In addition, there is a related university: Zhengzhou Institute of Aviation Industry Management, and a test area: Zhengzhou Airport Economic Comprehensive Experimental Zone which is also the focus of the aviation industry in Henan Province. Xinzheng Airport, as the air portal of Henan Province and one of the important domestic airports, is located in the test area. Xinzheng airport is responsible for most air transport tasks of Henan Province, and the transport sector accounted for more than $96 \%$ of the province's civil aviation transport. In addition, as the international airport of Zhengzhou, Xinzheng International Airport has many international flights to different countries, and these countries include Russia, Singapore, Japan, South Korea and so on. Here, there are now 32 passenger airlines, Passengers can easily fly to 73 cities at home and abroad through 116 routes [1]. Zhengzhou airport development status is as follows:

(1) Zhengzhou airport transport capacity continues to increase, passenger traffic steadily increased year by year. With the "Zhengzhou Airport Comprehensive Experimental Zone Planning" issued, Zhengzhou began a comprehensive construction phase of being an aviation hub. There are 31 airlines, including China Southern Airlines Henan Branch, operate at Zhengzhou Xinzheng International Airport. They have opened 82 routes, more than 1,400 flights per week. And these routes can reach 52 cities and regions.

(2) Rapid development of air transport and aviation logistics.

The construction of the comprehensive bonded zone in Zhengzhou aviation port area greatly improved the speed of goods transportation and saved the transportation time. Now with the large-scale promotion of e-commerce, online shopping has become a very popular way of shopping. The province's bonded port logistics center is also under way cross-border e-commerce services experimental work. If the pilot is successful, combined with the advantages of the Central Plains is located, Zhengzhou is expected to become the country's online shopping distribution center, which will further promote the rapid development of the aviation industry[2].

(3) The introduction of aviation-related industries, making the function of the airport area is increasingly perfect.

Now, the Zhengzhou airport area already has a comprehensive bonded area, export processing zones, bonded logistics center, container center station and other large projects [3]. In addition, it has attracted many electronic precision manufacturing, bio-medicine, optical materials and other industries to come. These high-end manufacturing and modern service industry will promote the prosperity of the industry in our province, at the same time, will also lead to the rapid development of aviation industry to achieve industry and industry rely on each other, and ultimately achieve common development [4].

\section{The problems in the development of aviation industry in Henan province}

The research of China's aviation industry started relatively late. In recent years, although in China's aviation technology and strength have been greatly improved, but compared with the developed countries there is still room for further 
improvement. Traditionally, Henan is an agricultural province. At the same time, because it is located in the middle of China, Henan Province has become a transportation hub. With China's comprehensive strength, the upgrading of international status, as well as industrial, high-end manufacturing, transportation development, the national and provincial governments have begun to focus on the development of aviation industry. However, due to various factors, there are still many problems the province's aviation industry in development of the province's aviation industry.

\subsection{Aviation industry has not yet formed industrial agglomeration}

From the above analysis of the development of aviation industry in Henan Province can be seen, there are only 13 spacecraft manufacturing enterprises, a related university, two research institutes in Henan Province [5]. But, the spacecraft manufacturing enterprises are small in size and scattered in layout, and the links between enterprises and enterprises are not much contact, and the products are not the core products of spaceflight, the competitiveness is not strong, the technology content is low and the branding is weak. And the research shows that there is a positive correlation between industrial agglomeration and competitiveness, if the industry is more dispersed, it is difficult to enhance industrial competitiveness, so the competitiveness of aviation industry in our province is not strong, in part because industrial agglomeration is not formed.

\subsection{The lack of high-end aviation industry talent}

There are dozens of colleges and universities in Henan Province. But, there is only one aviation university, which is undoubtedly an important constraint for the development of aviation industry in terms of my province. And Henan has not yet introduced policies conducive to the introduction of talent.

\subsection{The weak international cooperation and insufficient transport capacity of Zhengzhou Airport}

Zhengzhou International Airport is only with Japan, Korea, Singapore, Russia and other countries have flights, and other countries have not yet opened routes, from this we can see that its international cooperation is not strong. In addition, the Zhengzhou International Airport traffic exceeded 10 million in 2011. Compared with Xi'an, Wuhan, Chengdu and other regions, Zhengzhou is not only in time but also in the number fall behind of them. In addition, due to geographical and economic factors, the development of Henan's aviation industry is far behind the speed of the coastal areas, Henan aviation industry development foundation is weak, operational capacity and management level remain to be improved.

\subsection{The gradually increasing competitive pressure in the central region}

The province is building a pilot area of the airport, at the same time, the surrounding provinces and cities are also active in the airport planning and development. For example, Hubei is building Wuhan Tianhe Airport as the core of the Wuhan Airport; Hunan, Xi'an and other places are also actively develop their aviation industry, which undoubtedly has brought great pressure competition to the development of aviation industry in Henan Province.

\subsection{The environmental impact}

The environmental impact of the aviation industry mainly includes the following: (1) airport aircraft noise and equipment noise[6]; (2) combustion gas, wastewater, industrial wastewater; (3) the transport, production, storage of various types of hazardous chemical substances hazardous materials;(4) waste and garbage, produced by the surrounding industrial, will pollute the surrounding living environment; (5) the construction of large-scale aviation industry will cause soil erosion and impact on the ecological environment. As we all know, the pilot area of airport development belongs to regional linkage development. The impact of this regional development on the environment, not only from the scope of the impact, but also from the extent of the impact is much larger than a single enterprise, and with the continued activity, the impact will continue. Obviously, this departure from the green economy, low-carbon economy, and sustainable development policies, and long-term will restrict the development of the aviation industry [7].

\subsection{Innovation system and innovation ability need to be improved}

Since the establishment of the airport pilot area, the province's aviation industry has achieved initial results. The development of the aviation industry in our province cannot just copy the development model of other regions, and should have our own characteristics, innovation. In the initial stage of development of the aviation industry, Aviation industry has a strong technical dependence, and the pattern is probably the same. However, in the development stage, the province's aviation industry should take the road of collaborative innovation, and form the core competitiveness with regional characteristics.

\section{Responding measures to the development of aviation industry}


Henan Province's aviation industry is still in the stage of development and exploration. In the development process of a new industry will encounter many problems, only by daring to find problems, face these problems, and find the response measures to correct it, can make an industry more reasonable and perfect. The following countermeasures are put forward for the problems in the development of aviation industry of Henan Province:

\subsection{The formation of industrial agglomeration improves competitiveness of aviation industry}

Measures to enhance the competitiveness of the province's aviation industry are as follows: (1) the government should build an aviation research institute here, and increase investment in the aviation industry; (2) spacecraft production enterprises need to gather together, while strengthening the cooperation between our province aviation industry and advanced spacecraft enterprise;(3) the government should vigorously attracts foreign investment, and give those aviation industries who enter our province good policies to improve the construction of the airport pilot area system. Industrial agglomeration can facilitate the cooperation between enterprises, which not only can enhance the competitiveness of the aviation industry, promote the aviation industry well developed, but also can promote the local manufacturing industry, the development of the electronics industry, and promote the economic development of our province[8].

\subsection{Training and introducing high-end technical personnel}

Aviation industry is a high-end technology industry; the support of relevant high-tech talent is a necessary condition for its development. In the process of vigorously developing the aviation industry, Henan Province needs to pay attention to the cultivation and introduction of talents. And Zhengzhou Airport Economic Experimental Zone is in the construction stage, a large number of high-end talents are needed. The relevant government departments should also introduce relevant policies to attract and retain these senior personnel, so that they can devote themselves to the construction of the airport pilot area[2].

\subsection{Making full use of geographical and transportation advantages}

Henan is located in the Central of our country; here is the national transport hub. Henan Province is building an airport pilot area, which will open the door to the world. In recent years, Henan Province is focusing on building roads and the development of modern logistics. These measures to a large extent alleviate the competitive pressures brought by the surrounding areas. However, the Zhengzhou International Airport is located in Xinzheng, where is distance from Zhengzhou city, Zhengzhou Railway Station and high-speed rail stations, which gives passengers in the plane brought a lot of inconvenience. Therefore, a subway from the city to the airport should be built as soon as possible o facilitate passengers to travel.

\subsection{Building green city, strengthen ecological construction, and protect the environment}

In response to environmental pollution caused by the development of the aviation industry, the following measures can be taken: (1) rational planning and rational development. In the construction of the airport pilot area, government departments should lead the industrial layout, optimize the industrial structure, and actively respond to the national green economy, low-carbon development policy; (2) protecting the environment and providing reasonable supporting. In the process of development, the concept of environmental protection is not ignored. In the production process to reduce waste, to avoid unnecessary operations and steps to reduce industrial waste production and reduce machine noise; (3) green aviation city. Scientific planning urban service area, efficient use of land, creating green livable living environment, improving the transport system, all of them are service support for the development of the aviation industry;(4) ecological construction. The surrounding area of the test area needs to build more green landscape belts, so as to expand the green area and improve the greening rate.

\subsection{Promoting cross-border e-commerce services}

As mentioned above, our province is trying to pilot cross-border e-commerce services. With the prevalence of online shopping, the implementation of the pilot, is bound to greatly increase the capacity of our province's aviation, and promote the development of aviation industry in our province. Specific measures include the construction of e-commerce centers and cross-border network shopping items cluster evacuation center. E-commerce promotes the development of the real economy, $r$ to achieve the physical store and online store interactive development.

\subsection{Government should strengthen the guidance of the aviation industry and establish monitoring system}

Compared with the developed countries, China's aviation industry is still relatively backward. Our province is facing a weak foundation for the development of the aviation industry. Substantial progress is inseparable from the strong support of government departments. The government needs give more help in the capital, personnel and business introduction 
policies[9]. In addition, the aviation industry is an industry, the airport pilot area is a large area, where will involve a lot of money. At the same time, the aviation industry is involved in many national technology secrets, in order to avoid fraud, technology leaks and other phenomena, the government should set up the corresponding supervision system to ensure that the airport experimental zone in the right path of development on the rapid, healthy and harmonious development.

\section{Conclusions}

In the context of vigorous development of aviation industry, Henan Province should seize this historical opportunity to develop aviation industry in Zhengzhou pilot area as the core. On the one hand, high-end technology industries related to aircraft manufacturing can be developed, including the design of large body components, the manufacture of aircraft parts, the manufacture of aeronautical standard parts and the manufacture of light aircraft. On the other hand, develop logistics, e-commerce, technical services, human resources, entertainment, tourism and other modern services as the corresponding facilities. These will contribute to the formation of Aviation Industry Park with the characteristics of Henan province, the good wishes of aviation industry strides forward and rapid development of our province's economic.

\section{References}

1. Zhang Yan. Zhengzhou airport economic comprehensive experimental zoneresearch on talent requirement and development. Contemporary Economics, 12:90-91(2014).

2. Hao Ai-min. Research center of aeronautics \& economics, Zhengzhou institute of aeronautical industry management. Journal of Kaifeng University, 01:24-28(2014).

3. Guo Cheng. Study on the development of bonded logistics system in China. China Chuyun, 02:85-87(2011).

4. Xia Hong. Competitiveness of Chinese aviation industry: An analysis based on diamond model. Journal of Zhongzhou University, 05:18-22(2014).

5. He Shu-ping. The problems and countermeasures in the development of aviation industry.Journal of Zhengzhou Institute of Aeronautical Industry Management,2009(03).

6. Dong Xiao-lin, Yang Meng-yao. Relationship between industrial waste gas emission and control investment based on the pollution degree of investment index. Journal of Earth Science and Environment, 03:113-118(2013).

7. Bai Shu-wei. Study on the development path of low - carbon economy in Henan province .Zhengzhou University, 2013.

8. Wang Win-fei. The route choice of china aviation industry's future development. Nanjing University of Aeronautics and Astronautics,2008.

9. Wang Xue-feng, Feng De-xian, Yang Yan-zhe, Du Jun, Zhang Hong. Construction of Zhengzhou airport economic comprehensive experimental zone and its spatial organization of growth triangle in Zhengzhou-Kaifeng-Xuchang. Areal Research and Development, 2013(06). 